\title{
Exploring the peptide retention mechanism in Molecularly Imprinted Polymers
}

Cecilia Rossetti ${ }^{1}$, Odd Gøran Ore ${ }^{1}$, Börje Sellergren ${ }^{2}$, Trine Grønhaug Halvorsen ${ }^{1}$ and Léon Reubsaet ${ }^{1 *}$.

${ }^{1}$ Department of Pharmaceutical Chemistry, School of Pharmacy, University of Oslo, Oslo, Norway

${ }^{2}$ Department of Biomedical Sciences, Faculty of Health and Society, University of Malmö, Malmö, Sweden

\author{
AUTHOR INFORMATIONS. \\ Corresponding Author* \\ *Léon Reubsaet \\ Department of Pharmaceutical Chemistry, School of Pharmacy, University of Oslo, \\ P.O. Box 1068 Blindern, NO-0316 Oslo, Norway \\ j.I.reubsaet@farmasi.uio.no
}




\begin{abstract}
Molecularly Imprinted Polymers (MIPs) have been employed as useful sorbents in solid phase extraction (SPE) for a wide range of molecules and sample matrices. Their unique selectivity can be finetuned in the imprinting process and is crucial for the extraction of macromolecules from complex matrices such as serum. A relevant example of this is the MIP application to peptides in diagnostic assays. In this paper the selectivity of MIPs, previously implemented in the quantitative massspectrometric assay for the biomarker Pro Gastrin Releasing Peptide, has been investigated. Partial Least Square Regression (PLS) was used to generate models for the evaluation and prediction of MIPs retention mechanism. Hypothesis on MIPs interactions with the target peptide was verified by ad hoc experiments considering the relevant peptide physicochemical properties highlighted from the multivariate analysis. Novel insights and knowledge on the driving-forces responsible of the MIP selectivity have been reached and can be directly used for further optimization of MIPs imprinting strategies.
\end{abstract}

\title{
INTRODUCION
}

Molecularly Imprinted Polymers (MIPs) are synthetic receptors with capability of molecular recognition ${ }^{1-}$

2. This exceptional property originates from their specific polymerization, which occurs directly around the molecule to be recognized, and makes them relevant for a wide range of applications. Among them, the application of MIP to the sample preparation is a promising research area in the field of analytical chemistry $^{3-6}$. Many sample clean-up protocols have been developed for the extraction of small molecules from food, environmental and biological matrices ${ }^{7-12}$. The key behind the success of MIP employment in solid phase extraction (SPE) can be found in their robustness under extreme physical-chemical conditions and their time- and cost-effective synthesis. ${ }^{13}$ It is possible, in fact, to obtain ready-to-use MIPs in matter of hours, with relatively inexpensive reagents and still assuring high degree of selectivity ${ }^{14-16}$.

The evaluation of polymer selectivity is a crucial point, since it is desirable to drive the optimization of polymer synthesis according to the ability of the polymer binding-sites to discriminate between molecules with similar physical-chemical properties ${ }^{17-18}$. The evaluation of the effectiveness of the polymer binding sites is generally performed by direct comparison between the retention of MIP and the related NonImprinted Polymer (NIP). The two polymers are in fact synthetized by using the same protocol with the exception of the addition of the template-molecule which is omitted in the NIP. No analyte specific retention is thus expected from the NIPs due to the absence of sterically positioned binding sites, but this 
occurrence is rarely verified due to the occurrence of many different interactions between polymer and molecule ${ }^{19}$.

A new trend in MIP-SPE is the extraction of macromolecules such as peptides and proteins ${ }^{20-25}$. These applications have just risen from the recent development of imprinting strategies due to the complexity of imprinting macromolecules. This has to take in account many different interactions, simultaneously occurring around the template molecule, and the template insolubility into organic solvents generally used for the polymeric synthesis ${ }^{26-27}$. However, several MIPs have been developed for peptide enrichment and employed in the sample preparation of proteomic workflows ${ }^{28-35}$.

An application of great interest for tryptic peptide selective MIPs is the integration in diagnostic assays for severe diseases such as the aggressive tumor Small Cell Lung Cancer (SCLC) ${ }^{36-37}$ (manuscript submitted). In these studies, MIPs selective for the signature peptide (NLLGLIEAK) of the biomarker Pro Gastrin Releasing Peptide (ProGRP) were developed to be explored for their use in the diagnosis of SCLC. The enrichment of NLLGLIEAK allowed the quantification of ProGRP directly from serum samples by a massspectrometric assay. Due to the wide protein concentration range in serum and, at the same time, to the limited dynamic range of the mass spectrometer, the selectivity of the MIP becomes a crucial factor to be evaluated and emphasized by the experimental conditions. The analysis of the species co-extracted with NLLGLIEAK in the MIP cartridge allowed the identification of many peptides belonging to serum albumin ${ }^{37}$, but limited information was achieved about the interactions playing fundamental roles in peptide retention.

Deeper understanding and prediction of peptide retention on different chromatographic systems have been achieved by multivariate analysis, where Design of Experiment (DoE), Principal Component Analysis (PCA) and Partial Least Square regression (PLS) were used for the identification of peptide properties which mainly affect the chromatographic retention ${ }^{38-41}$. This powerful approach allows the simultaneous screening of many variables influencing the studied system with the advantage to achieve a more complete overview on the variables effects and interactions with a limited amount of experiments. Moreover, the prediction of the chromatographic response can be used to hypothesize the retention of different peptides, which are not tested yet.

The aim of this paper was to evaluate the retention mechanism of tryptic peptides in MIPs and related NIPs selective for the signature peptide NLLGLIEAK. The initial hypothesis on the correlation between retention and peptides physicochemical properties was investigated by multivariate analysis using PLS regression. Also the polymers composition and the functional monomer orientation were evaluated by exploring the $\mathrm{pH}$ influence on peptides retention. The SPE experiments were performed using tryptic 
peptides from bovine serum albumin (BSA) as well as the target analyte NLLGLIEAK, and the extractions were analyzed using liquid chromatography coupled to mass spectrometry (LC-MS).

Moreover the $\mu$-SPE formats were here used for the packing of the EAMA.HCl-based MIPs and NIPS previously employed for the off-line extraction of NLLGLIEAK from serum samples ${ }^{42}$.

\section{MATERIALS AND METHODS}

Reagents and Standards. BSA with purity above 96\% (Sigma-Aldrich, Germany) was dissolved in $50 \mathrm{mM}$ freshly prepared ammonium bicarbonate $(A B C)$ buffer and subsequently diluted to a final concentration of $48 \mathrm{nM}$. The target peptide NLLGLIEA $\left[\mathrm{K}_{-}{ }^{13} \mathrm{C}_{6}{ }^{15} \mathrm{~N}_{2}\right.$ ] was purchased as AQUA Peptide and diluted according to the Custom AQUA Peptides Storage and Handling Guidelines by Sigma-Aldrich to a final concentration of $10 \mathrm{nM}$. TPCK-treated lyophilized trypsin from bovine pancreas was sequencing grade (Sigma-Aldrich). All the solutions were stored at $-20^{\circ} \mathrm{C}$. The MIP sorbents and the corresponding NIPs were provided from University of Malmö (Sweden) and prepared as described elsewhere ${ }^{42}$. All other chemicals used were of analytical grade.

Sample preparation. The solution of BSA was spiked with the solution of the target peptide to a final concentration of $10 \mathrm{nM}$, reduced with a volume of $2.5 \mu \mathrm{L} 50 \mathrm{mM}$ DTT in $50 \mathrm{mM}$ ABC-buffer and subsequently incubated at $800 \mathrm{rpm}$ at $60^{\circ} \mathrm{C}$ for $20 \mathrm{~min}$. The solution was then cooled down and $2.5 \mu \mathrm{L}$ $200 \mathrm{mM}$ IAA in $50 \mathrm{mM}$ ABC-buffer were added. Incubation was carried out for $15 \mathrm{~min}$ at room temperature in the dark. Digestion was accomplished by adding trypsin diluted in $50 \mathrm{mM} \mathrm{ABC}$-buffer in order to achieve an enzyme : substrate ratio of $1: 40$.

MIP and NIP packing into $\mu$-cartridges. The MIP and NIP materials were packed into micro-column using Bevel Point ${ }^{\mathrm{TM}}$ pipette-tips (1-300 $\mu \mathrm{l}, \mathrm{VWR}$ ) equipped with a polyethylene disk (20 $\mu \mathrm{m}$ pore size) plugged at the bottom of the tips. Ten $\mathrm{mg}$ of each polymer were initially conditioned and vortexed in $250 \mu \mathrm{L}$ of acetonitrile (MeCN). Subsequently $20 \mu \mathrm{L}$ of the polymer slurry (containing approx. $800 \mu \mathrm{g}$ of sorbent) were quickly pipetted into the pipette tips. After $3 \mathrm{~min}$ of centrifugation at $3000 \mathrm{rpm}$, the polymers were pulled down in a pellet and the supernatant solvent was removed allowing the use of the tips for the further SPE experiments. Three different $\mu$-cartridges were prepared for each MIP and NIP polymer.

SPE experiments. Two sets of SPE experiments were performed on both MIP and NIP by applying different organic strengths and $\mathrm{pHs}$.

Organic strength variation: All the cartridges were conditioned and activated by sequentially pipetting $100 \mu \mathrm{L}$ of $\mathrm{MeOH}$ and $\mathrm{ABC}$-buffer ( $50 \mathrm{nM}$ ) and solvents were discharged by centrifugation ( 3 min at 7000 rpm). Then $50 \mu \mathrm{L}$ of the digested spiked BSA was applied and sequential washes of the cartridges were 
performed by $50 \mu \mathrm{L}$ of wash solvents with increased MeCN content $(5 ; 10 ; 15 ; 20 ; 25 ; 30,35$ and $40 \%)$ in Milli-Q water. The final elution was performed with $50 \mu \mathrm{L}$ of eluent ( $80 \% \mathrm{MeCN}, 3 \%$ Formic Acid (FA), $17 \%$ Milli-Q water) in order to elute the eventual peptides still retained in the cartridges.

$\mathrm{pH}$ variation: After activation with $100 \mu \mathrm{L}$ of $\mathrm{MeOH}$ four parallel experiments were conducted by performing the condition of the columns with $100 \mu \mathrm{L}$ of $50 \mathrm{mM}$ of $A B C$-buffer at four different pHs (acidified with FA $2 \mathrm{M}$ to a final pH of 2.2 and with FA $20 \mathrm{mM}$ to $\mathrm{pH}$ 7.1, adjusted with $\mathrm{NH}_{3} 1 \mathrm{M}$ to $\mathrm{pH} 9.5$ and with $\mathrm{NaOH} 13 \mathrm{M}$ to $\mathrm{pH}$ 12.0). After the sample load, the cartridges were washed with solutions of 7.5 \% $\mathrm{MeCN}$ in water adjusted to $\mathrm{pH} 2.2,7.1,9.5$ and 12.0 with FA $2 \mathrm{M}, \mathrm{FA} 20 \mathrm{mM}, \mathrm{NH}_{3} 1 \mathrm{M}$ and $\mathrm{NaOH} 13 \mathrm{M}$ respectively. The final elution was performed as described above for all cartridges.

Liquid Chromatography (LC)-LTQ-Orbitrap analysis of extracted serum samples. All the fractions collected from the SPE experiments and the unextracted samples were diluted 1:10 with $20 \mathrm{mM} F A$ and injected into the LC-LTQ-Orbitrap system. The Dionex Ultimate 3000 chromatographic system was controlled by Chromeleon Xpress and comprised an ISO 3100 SD loading pump, an LPG 3400 M micropumps, a WPS 300 TRS autosampler and an FLM 3300 B NANO flow-manager (all Dionex, Sunnyvale, CA, USA). The LTQ Discovery Orbitrap Mass spectrometer was controlled by Xcalibur and equipped with a Nano-ESI ion source (all Thermo Fischer, Bremen, Germany). For each sample $10 \mu \mathrm{L}$ were injected into the system. The loading mobile phase, $20 \mathrm{mM} F A$ and $\operatorname{MeCN}(97: 3, \mathrm{v} / \mathrm{v})$ trapped the samples on a C18 Acclaim PepMap 100 enrichment column (300 $\mu$ m i.d. $\times 5$ mm, $5 \mu \mathrm{m}$; Thermo Fischer) for 4 min with a flowrate of $10 \mu \mathrm{L} / \mathrm{min}$. The analytes were consequently transferred to a C18 Acclaim PepMap 100 analytical column (75 $\mu$ m i.d. $\times 15 \mathrm{~cm}, 3 \mu \mathrm{m}$; Thermo Fischer) at $300 \mathrm{~nL} / \mathrm{min}$ by mobile phase A ( $20 \mathrm{mM} \mathrm{FA:} \mathrm{MeCN} \mathrm{95:5} \mathrm{(v/v)}$ ). A linear gradient increased the concentration of mobile phase $B(20 \mathrm{mM} \mathrm{FA}$ and MeCN 5:95 (v/v)) from 0 to $50 \% \mathrm{~B}$ in $60 \mathrm{~min}$, and then to $100 \% \mathrm{~B}$ for $4 \mathrm{~min}$. Re-equilibration of the column was performed with mobile phase A solely. The total analysis time per run was $89 \mathrm{~min}$. The nanospray ionization source was operated in the positive ionization mode with a spray voltage set at $2.2 \mathrm{kV}$ and a capillary voltage set at $45 \mathrm{~V}$. The heated capillary was kept at $150^{\circ} \mathrm{C}$ and the tube lens offset at $100 \mathrm{~V}$. Data-dependent acquisition was performed at a resolution of 30000 over a mass range between $\mathrm{m} / \mathrm{z}$ 250-2000 Da with charge state disabled in the Orbitrap mass analyzer. The six most intense ions per scan were fragmented by CID at 35 $\%$ relative collision energy (activation time $30 \mathrm{~ms}$ ) and analyzed in the linear ion trap. The fragmented $\mathrm{m} / \mathrm{z}$ values were dynamically excluded for 15 seconds in order to minimize the extent of repeat sequencing of peptides and to fragment also lower intensity $m / z$ values.

Peptide identification. The MS raw files were processed with Proteome Discoverer 1.4 (Thermo Fischer, Bremen, Germany), using the SEQUEST algorithm, searching against a FASTA file containing BSA peptides 
sequences generated from UniProtKB ${ }^{43}$. Up to 3 missed cleavages were considered using trypsin as enzyme. Methionine oxidation was chosen as variable modification and Cystein carboxymethylation was chosen as static side chain modification. The precursor and fragment ion mass tollerance was set to 10 ppm and 0.8 Da, respectively. Peptide identification was accepted with FDR $<0.01 \%$

Determination of peptide recoveries. The identified tryptic peptides together with NLLGLIEA $\left[K_{-}{ }^{13} \mathrm{C}_{6}{ }^{15} \mathrm{~N}_{2}\right]$ were then manually checked in the extracted ion chromatograms (XICs) and verified by the mean of their fragmentation pattern, using the Xcalibur's $\mathrm{s}^{\mathrm{TM}}$ QualBrowser software version 2.1 (Thermo Fischer, Bremen, Germany). The peak areas of selected peptides were processed by genesis peak detection algorithm, considering only peaks with signal-to-noise (S/N)-ratio above 10.

The recovery for each peptide was calculated dividing the chromatographic peak area generated in the extracted samples by the peak area of the unextracted sample. Experimental replicates were then averaged and normalized for the total recovery achieved in each experiment.

Retention Model. The Unscrambler ${ }^{\circledast}$ program version 9.8 was used for the modeling of peptide retention on both MIP and NIP SPE experiments. Partial least square (PLS) regression was used to model the descriptors (X variables) of the selected peptides (samples) to predict the retention on MIP and NIP cartridges ( $Y$ response). The regression was performed in PLS 1 mode which predicts one $Y$ response at the time. Both $X$ variables and $Y$ responses were auto-scaled by dividing each value for the standard deviation. Random cross validation was applied during the calculation to build the model by including 2 samples in each segment to be excluded in turn from the training set. The Martens uncertainty test based on the so-called "Jack-knife" resampling ${ }^{44}$ was applied during the calculation in order to evaluate the significance of each descriptor contributing to the model. Three principal components were chosen to build the model.

\section{RESULTS AND DISCUSSIONS}

MIP and NIP $\mu$-cartridges. The use of $\mu$-cartridges packed with MIP and NIP materials allowed the off-line extraction of the digested samples with low consumption of sample volume (50 $\mu \mathrm{L})$ and low sorbent amount $(800 \mu \mathrm{g})$. Moreover such format allowed the parallel extraction of the SPE replicates which was particularly of advantage in terms of analysis time and recovery reproducibility.

Elution profile of BSA peptides on MIP and NIP cartridges. The retention of BSA tryptic peptides and NLLGLIEA $\left[K_{-}{ }^{13} \mathrm{C}_{6}^{15} \mathrm{~N}_{2}\right]$ was investigated for MIP and NIP cartridges in order to evaluate retention differences and similarities among peptides with known physical and chemical properties. The use of BSA as model protein was driven from its simplicity of digest, purchase and its revised annotation in UniProt 
database. Moreover serum albumin is the most abundant protein in serum, the matrix of choice for the detection of ProGRP, and a recent study showed strong albumin retention on a MIP cartridge developed for the quantification of ProGRP in serum ${ }^{37}$. Hence the use of BSA as model system would mimic the human serum albumin in patient samples and hopefully would result in valuable information about the albumin peptides observed previously [37]. Thus a sequential elution with increasing organic solvent strength was performed using the target peptide NLLGLIEA $\left[\mathrm{K}_{-}{ }^{13} \mathrm{C}_{6}{ }^{15} \mathrm{~N}_{2}\right]$ and the peptides coming from the digestion of BSA $48 \mathrm{mM}$, which allowed good MS signal intensities without cartridge overload. The elution profile (plotted as cumulative recovery vs. percentage of organic solvent) for each peptide is shown in Figure 1 and Figure 2 for MIP and NIP cartridges, respectively. The recovery of each peptide was measured using the extracted ion chromatograms (XIC) areas and recovery values range between 0 and 1 due to the normalization performed based on the total elution. Peptide elution profiles slightly differ between MIP and NIP. Among all the considered peptides, NLLGLIEA $\left[\mathrm{K}_{-}{ }^{13} \mathrm{C}_{6}{ }^{15} \mathrm{~N}_{2}\right]$ is one of the most retained in both MIP and NIP cartridges, together with KVPQVSTPTLVEVSR, KQTALVELLK and LGEYGFQNALIVR from BSA. From the different elution profiles hypothesis on the increased retention for peptides with long amino acidic sequence can be supposed.

Peptide retention model. In order to obtain more detailed knowledge on the correlation of the peptide's physical-chemical properties with their elution profiles from the two different sorbents, a model was built by using multivariate regression. The model used PLS in order to identify which of the peptide properties $(\mathrm{X})$ contributed most to the difference in peptide retention $(\mathrm{Y})$. The choice of the peptide variables to be considered reflected a preliminary hypothesis of the polymers interacting groups and agreed with the variables previously chosen for the PCA of peptide retention in RP-LC ${ }^{41}$. By using linear combination of the initial variables, it was possible to pinpoint the ones that contribute most to the variation among the samples. Their response was useful to discriminate among physicochemical properties which do not influence peptide retention. As output of the model $(\mathrm{Y})$, a defined value was calculated for each peptide retention by determining the corresponding $\mathrm{MeCN}$ amount needed to achieve $50 \%$ recovery of each peptide. As a result, a matrix was built (Table 1 ) and used to generate the PLS model by using the following different peptide descriptors: number of amino acids, number of negative charges, number of positive charges, number of aromatic residues, molecular weight, gravy index, isoelectric point, aliphatic index and the percentage of MeCN required to achieve 50\% recovery in the MIP and NIP cartridge (NIP). Figure 3 Score plotshows the score plot related to the MIP retention model. The considered peptides are homogeneously distributed along the first component, which explains $59 \%$ of the total variance. The target peptide NLLGLIEA $\left[K_{-}{ }^{13} \mathrm{C}_{6}{ }^{15} \mathrm{~N}_{2}\right]$ is overlapped with QTALVELLK far from the origin. Since their position 
in the score plot is in the direction of the maximized variance, we can infer that these samples have a relevant impact on the retention model. From a first screening of the peptide distribution, it can be distinguished between peptides with long amino acid sequence, mainly lying in the left part of the plot, and peptides with short amino acid sequence in the right part of the graph.

This observation can be explained by the analysis of the MIP correlation loadings plotted in

Figure 4 Correlation loadings plotwhere the first component is dominated by all the variables used to describe the model. The molecular weight of the peptides $(\mathrm{Mw})$ and the number of amino acids (AA\#) are positioned in the left part of the plot, supporting the previous findings on the distribution of longer peptides in the left part of the score plot (figure 3). A close correlation can be supposed among the variables since none of the variables are orthogonal to each other. The negative charges on the peptide seem to impact the MIP retention negatively, since MIP and negative charge have opposite directions

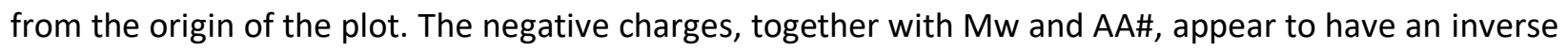
correlation with the variables on the right side of the plot. These variables (iso-electric point, aliphatic index and Gravy value) are closely correlated and contribute positively on MIP retention (the same direction in the first principal component (PC)). By looking at the influence of each variable on the MIP retention, we can predict that both negative charge and iso-electric point $(p /)$ will probably have significant impact on MIP retention. Variables as Mw and positive charge of the peptide are not expected to have a relevant effect on the MIP retention since their orthogonal projection on MIP direction falls close to the plot origin.

The regression coefficients of the MIP model in Figure 5 Regression coefficient give a clearer indication of the importance of the variables in the obtained MIP model. According the absolute value of the regression coefficients and their error bars determined by Martens uncertainty test, the negative charge and the $\mathrm{pl}$ of the peptides give significant contribution to the retention model. This means that MIP selectivity is highly affected by these two peptide properties and this circumstance could be easily explained by the interaction established within the polymer chains by the functional monomer EAMA. $\mathrm{HCl}$ which is positively charged at $\mathrm{pH}$ below 10 .

Many similarities with this model can be found by looking at NIP model. The score plot in Figure 6 Score plotshows a similar peptide distribution in the first 2 PCs as the MIP model (Figure 3 Score plot of the MIP model. Moreover, the majority of the variance is again mainly explained by the first PC (58\%) and the distribution of larger peptide is in the left area of the plot.

The correlation loadings plot shown in Figure 7 Correlation loadings plot can also be closely compared with the MIP model. All the variables are directly or inversely correlated, since they are distributed along 
the two sides of the first PC. The Mw, the AA\# and the negative charges of the peptides seem to negatively impact the NIP retention as well, being in the left part of the plot, opposite to the NIP elution response. By the analysis of regression coefficients, a slight difference can be found in the NIP model (Figure 8 Regression coefficient) where the negative charges are not significant as in the MIP model, while the p/ plays a significant role also for the NIP model. Other variables such as the number of aromatic residues and the aliphatic index have a significant contribution for the model description.

Figure 9 and Figure 10 show the regressions of the obtained models from MIP and NIP extractions. As mentioned above, the plots show the measured vs the predicted elution in terms of acetonitrile percentage required to complete $50 \%$ elution of each considered peptide. Both MIP and NIP calibration models (blue lines) have rather good correlations with $\mathrm{R}^{2}$ values above 0.7 while the cross-validated models (red lines) show a better correlation for the MIP model $\left(R^{2}=0.69\right.$ in MIP model and $R^{2}=0.52$ in NIP model). The slopes of the models indicate the prediction accuracy: the closer to the value of 1 , the better the regression lines agrees with the target line (black line), where a perfect linear correspondence occurs between measured and predicted elution values. Again, better prediction is shown for the MIP model. The root mean squared error (RMSE) is smaller in the MIP model than in the NIP in both calibrated and validated models, indicating a better prediction of the MIP model.

From these results, we can assume that the models obtained by the regression of the peptide physicalchemical properties with peptide elution in MIP and NIP cartridges can give an accurate idea of the peptide properties which are most relevant for the retention in the polymeric cartridges. In both models the $\mathrm{p} /$ value seems to influence the retention of the peptides in both MIP and NIP, thus a detailed investigation on the influence of $\mathrm{pH}$ in the retention of the target peptide was performed.

pH influence on peptide retention. Figure 11 Influence of the loading pH on the NLLGLIEA[K_ ${ }^{13 C 615 N 2}$ ] recovery shows the normalized recovery from the extraction of NLLGLIEA $\left[\mathrm{K}_{-}{ }^{13} \mathrm{C}_{6}{ }^{15} \mathrm{~N}_{2}\right]$ when the pH of the sample loading and washing solutions ranges from 2.2 to 12.0. It should be noted that the elution conditions are chosen such that all the remaining NLLGLIEA $\left[\mathrm{K}_{-}{ }^{13} \mathrm{C}_{6}{ }^{15} \mathrm{~N}_{2}\right]$ will elute from both MIP and NIP thus the figure only shows the effect of the $\mathrm{pH}$ in the sample loading step and in the washing step. The choice of this $\mathrm{pH}$ range was driven by the combination of $\mathrm{p} K_{\mathrm{a}}$ values of the functional monomer taking place in both MIP and NIP polymers and in the acidic residues occurring in NLLGLIEA $\left[\mathrm{K}_{-}{ }^{13} \mathrm{C}_{6}{ }^{15} \mathrm{~N}_{2}\right]$. The figure clearly shows the great impact of the sample load pH on NLLGLIEA $\left[\mathrm{K}_{-}{ }^{13} \mathrm{C}_{6}{ }^{15} \mathrm{~N}_{2}\right]$ retention. The impact of low and high $\mathrm{pH}$ allows the same retention behavior in MIP and NIP cartridges: both levels shows reduced retention: at $\mathrm{pH} 2.2$ the functional monomer EAMA. $\mathrm{HCl}$ is positively charged and the peptide Cterminal carboxylic acid $\left(p K_{\mathrm{a}} 2.2\right)$ is negatively charged. However, only $10 \%$ of the glutamic acid of the 
peptide is negatively charged $\left(\mathrm{p} K_{\mathrm{a}} 4.2\right)$ thus the interaction of this group with the polymer is weak. Likewise at $\mathrm{pH} 12.0$ the possibility of ionic interaction is reduced as the EAMA. $\mathrm{HCl}$ is not charged ( $\left.K_{\mathrm{a}} 9.6\right)$. A large portion of NLLGLIEA $\left[\mathrm{K}_{-}{ }^{13} \mathrm{C}_{6}{ }^{15} \mathrm{~N}_{2}\right]$ is then be lost during peptide sample load and wash of both MIP and NIP cartridges.

At pH 9.5 and pH 7.1 both MIP and NIP cartridges show a strengthening of the interactions between EAMA. $\mathrm{HCl}$ and the negative charges of both glutamic acid and the $\mathrm{C}$-terminal carboxylic acid occurring in the peptide. These observation agree with a previous study where the increase of the loading $\mathrm{pH}$ up to 8.6 increased NLLGLIEA $\left[\mathrm{K}_{-}{ }^{13} \mathrm{C}_{6}{ }^{15} \mathrm{~N}_{2}\right.$ ] retention into an on-line MIP-cartridge (manuscript submitted).

An interesting observation of this experiment is the differential decrease in NLLGLIEA $\left[K_{-}{ }^{13} \mathrm{C}_{6}{ }^{15} \mathrm{~N}_{2}\right]$ retention between MIP and NIP at $\mathrm{pH}$ 2.2. The NIP cartridge has a minor decrease in target peptide retention than MIP (almost $80 \%$ of peptide recovery in NIP elution compared to the $20 \%$ of MIP elution). The reason of such retention can primarily be found in the interaction between the still charged C-terminal of the peptide, as occurring in the MIP cartridge, but an additional retention source could be ascribed to the interactions taking place between the divinyl benzene (DVB), which constitutes the main structure of the polymers, and the aliphatic and aromatic groups of the peptide. These contributions have been shown to be more significant in the NIP retention model than in the MIP one and this occurrence suggests the probable attribution to those of the additional NIP retention when peptide charges are minimized at $\mathrm{pH}$ 2.2. An hypothetical explanation of the reason why the aforementioned contributions affect less the MIP retention could be found in the structural organization of the EAMA. $\mathrm{HCl}$ within the polymer. In fact in the MIP polymer as the polymerization provides the addition of the template molecule at the beginning of the synthetic process, the template arranges and organizes the directions of the functional monomer EAMA. $\mathrm{HCl}$ before the addition of the cross-linker DVB, which makes the polymeric reticulation grow. In the NIP polymer, instead, the absence of the template causes a random incorporation of EAMA.HCl. These circumstances could cause the retention differences of the polymers since the MIP polymer mainly completes its molecular recognition inside the binding sites where the functional monomers are properly directed, thus their contribution to the peptide retention is substantial. Viceversa, such contribution becomes less effective in the NIP polymer, being the EAMA.HCl randomly distributed and oriented, but the interaction with the polymer skeleton becomes more significant due to the controlled reticulation which do not present distortions caused by the presence of the binding sites within the polymeric structure. This circumstance could explain also why the hydrophobic interactions established with the high acetonitrile content in the elution phase give better recovery in NIP cartridges then MIP in all the experiments. 


\section{CONCLUSION}

In this paper, multivariate analysis was successfully applied for the design of MIP and NIP retention models. Deeper understanding of the peptide interactions occurring within the polymers has been achieved and verified by a tailored experiment screening the $\mathrm{pH}$ influence on NLLGLIEAK retention.

The novel $\mu$-SPE cartridges were produced for the first time using EAMA.HCl-based MIPs and NIPs and revealed to be an adequate and valuable format for the qualitative screening of serum albumin peptides retained into the polymers. Low polymer amount, low sample and solvent consumption permitted parallel extraction replicates, increasing the accuracy of the experimental data.

The PLS models showed that in both MIP and NIP the $\mathrm{p} /$ was a significant peptide property affecting the retention. In the MIP model, the increase of the negative charge on the peptides was shown to contribute positively to the peptide retention, while in the NIP model the aliphatic index and the aromatic groups positively contributed to the peptide retention.

Investigation of the influence of the $\mathrm{pH}$ on sample loading, washing and elution shows that MIP the retention is mainly driven from the electrostatic interactions occurring between the peptides and the welloriented functional monomers (EAMA. $\mathrm{HCl}$ ) within the polymer binding sites. This circumstance is fundamental for the MIP selectivity. In NIP cartridges on the other hand, the main driving-force for the peptide retention is the presence of aliphatic and aromatic groups able to establish strong retention with the highly ordinated DVB skeleton of the polymer. Despite assuring high peptide recoveries, these nonspecific interactions are responsible for scarce selectivity in complex matrices as serum.

By using a simple protein model such as BSA and helpful statistical tools such as multivariate analysis deeper understanding on peptide interactions with MIP and NIP have been achieved. This knowledge will be useful for the design and optimization of novel MIPs synthesis. Further investigations and statistical evaluation on larger peptide dataset could represent a rapid innovation boost for the production of highly sensitive and retentive tryptic peptide-MIPs with application to clinical diagnostics.

\section{ACKNOWLEDGMENT}

This work has been performed as part of the 'Robust affinity materials for applications in proteomics and diagnostics' (PEPMIP) project, supported by the Seventh Research Framework Programme of the European Commission. Grant agreement number-264699 and from the Research Council of Norway (Grant agreement number-226654/F11). Authors would like to acknowledge also Abed Abdel Qader from Malmö University for the production of MIPs and NIPs object of the study. 
FIGURES

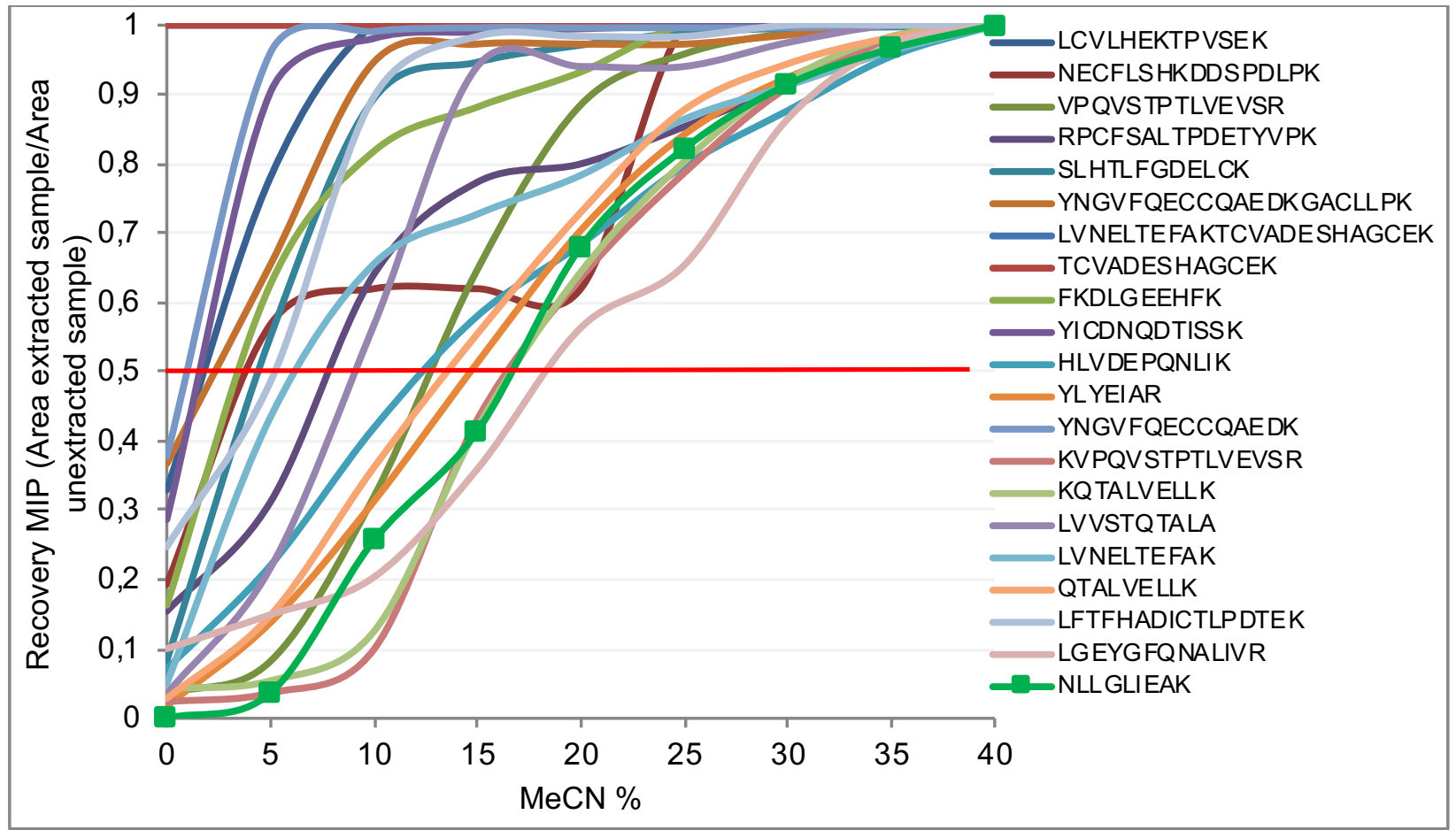

Figure 1 Cumulative recovery of the serum albumin peptides from MIP cartridge plotted versus the acetonitrile percentage (MeCN \%) applied for each elution step.

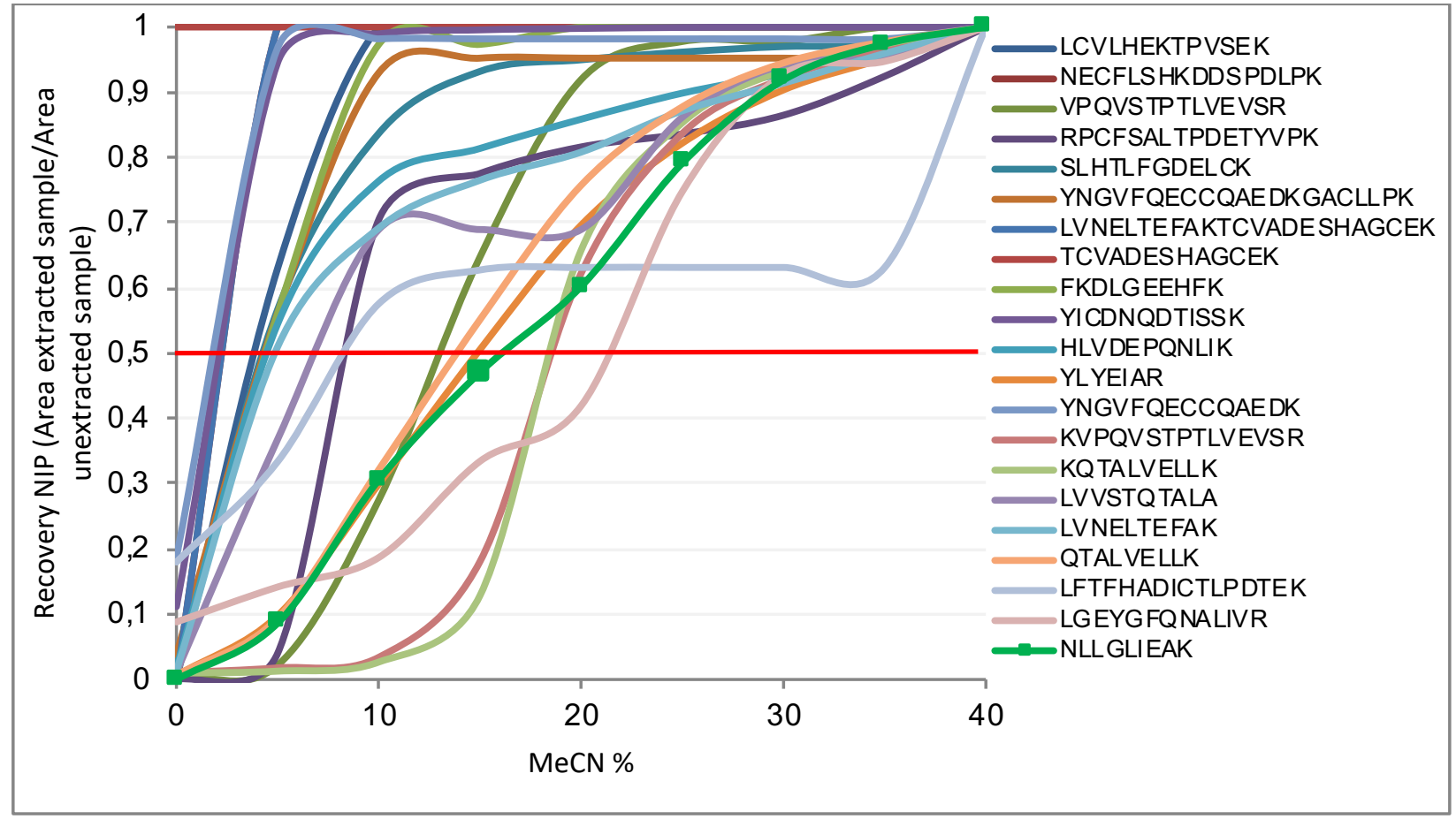

Figure 2 Cumulative recovery of the serum albumin peptides from NIP cartridge plotted versus the acetonitrile percentage ( $\mathrm{MeCN} \%$ ) applied for each elution step. 
Table 1 Extracted peptides and their molecular descriptors: number of amino acids (\# AA), number of negative charges (\# neg. charge), number of positive charges (\# pos. charge), number of aromatic residues (\# Aromatic), molecular weight (Mw), gravy index (Gravy), isoelectric point (pl), aliphatic index (AI) and the percentage of MeCN required to achieve $50 \%$ recovery in the MIP cartridge (MIP) and NIP cartridge (NIP).

\begin{tabular}{|c|c|c|c|c|c|c|c|c|c|c|}
\hline Peptides & $\# A A^{*}$ & \# neg. charge ${ }^{*}$ & \# pos. charge ${ }^{*}$ & \# Aromatic ${ }^{*}$ & $\mathrm{Mw}(\mathrm{g} / \mathrm{mol})^{*}$ & Gravy $^{\#}$ & $\mathrm{pl}^{\#}$ & $\mathrm{Al}^{\#}$ & MIP & NIP \\
\hline LCVLHEKTPVSEK & 13 & 2 & 2 & 0 & 1482.75 & 0.20 & 6.75 & 104.62 & 1.5 & 4.0 \\
\hline NECFLSHKDDSPDLPK & 16 & 4 & 3 & 1 & 1845.00 & 1.28 & 4.31 & 48.75 & 4.0 & 0.0 \\
\hline VPQVSTPTLVEVSR & 14 & 1 & 1 & 0 & 1511.72 & 0.21 & 6.84 & 110.71 & 13.0 & 13.0 \\
\hline RPCFSALTPDETYVPK & 16 & 2 & 2 & 2 & 1824.06 & 0.54 & 6.18 & 48.75 & 8.0 & 8.0 \\
\hline SLHTLFGDELCK & 12 & 2 & 2 & 1 & 1362.55 & 0.06 & 5.17 & 97.50 & 4.0 & 4.50 \\
\hline YNGVFQECCQAEDKGACLLPK & 21 & 3 & 2 & 2 & 2316.6 & 0.32 & 4.32 & 60.48 & 2.5 & 4.5 \\
\hline LVNELTEFAKTCVADESHAGCEK & 23 & 5 & 3 & 1 & 2494.76 & 0.23 & 4.24 & 72.17 & 0.0 & 2.0 \\
\hline TCVADESHAGCEK & 13 & 3 & 2 & 0 & 1349.45 & 0.52 & 4.31 & 37.69 & 0.0 & 0.0 \\
\hline FKDLGEEHFK & 10 & 3 & 3 & 2 & 1249.39 & 1.25 & 5.34 & 39.00 & 3.5 & 4.5 \\
\hline YICDNQDTISSK & 12 & 2 & 1 & 1 & 1386.50 & 0.83 & 3.88 & 65.00 & 1.5 & 2.0 \\
\hline HLVDEPQNLIK & 11 & 2 & 2 & 0 & 1305.50 & 0.58 & 5.21 & 132.73 & 12.5 & 4.5 \\
\hline YLYEIAR & 7 & 1 & 1 & 2 & 927.07 & 0.07 & 6.82 & 125.71 & 15.0 & 15.0 \\
\hline YNGVFQECCQAEDK & 14 & 3 & 1 & 2 & 1633.78 & 0.91 & 3.83 & 27.86 & 1.0 & 2.0 \\
\hline KVPQVSTPTLVEVSR & 15 & 1 & 2 & 0 & 1639.91 & 0.07 & 10.09 & 103.33 & 16.5 & 18.5 \\
\hline KQTALVELLK & 10 & 1 & 2 & 0 & 1142.41 & 0.19 & 9.88 & 156.00 & 16.5 & 18.5 \\
\hline LVVSTQTALA & 10 & 0 & 0 & 0 & 1002.18 & 1.39 & 6.01 & 156.00 & 9.0 & 7.0 \\
\hline LVNELTEFAK & 10 & 2 & 1 & 1 & 1163.34 & 0.13 & 4.26 & 117.00 & 6.0 & 5.0 \\
\hline QTALVELLK & 9 & 1 & 1 & 0 & 1014.23 & 0.64 & 6.94 & 173.33 & 13.5 & 14.0 \\
\hline LFTFHADICTLPDTEK & 16 & 3 & 2 & 2 & 1851.11 & 0.04 & 4.30 & 79.38 & 5.0 & 21.5 \\
\hline LGEYGFQNALIVR & 13 & 1 & 1 & 2 & 1479.70 & 0.29 & 6.89 & 120.00 & 16.5 & 18.5 \\
\hline NLLGLIEAK & 9 & 1 & 1 & 0 & 978.60 & 0.71 & 6.94 & 184.44 & 16.5 & 16.0 \\
\hline
\end{tabular}

"http://pepcalc.com; " http://web.expasy.org/protparam 


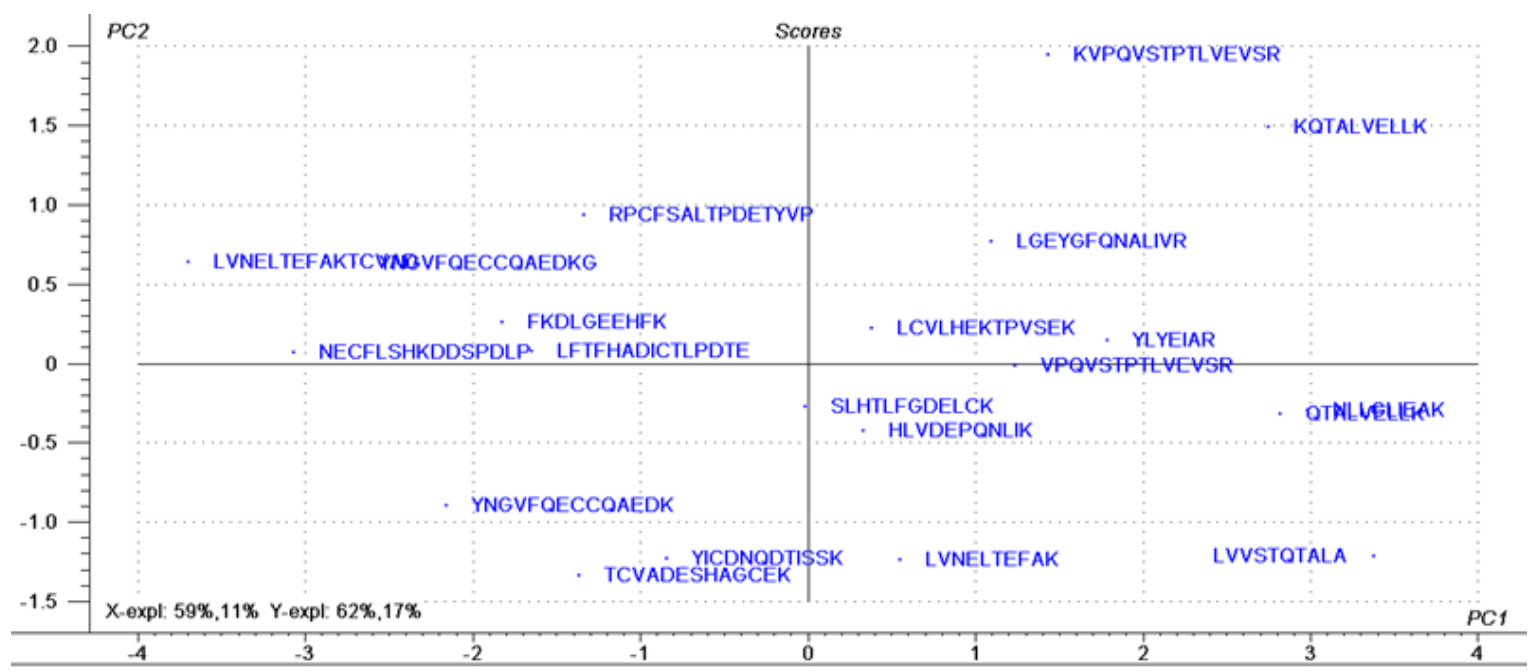

Figure 3 Score plot of the MIP model on the first two components.

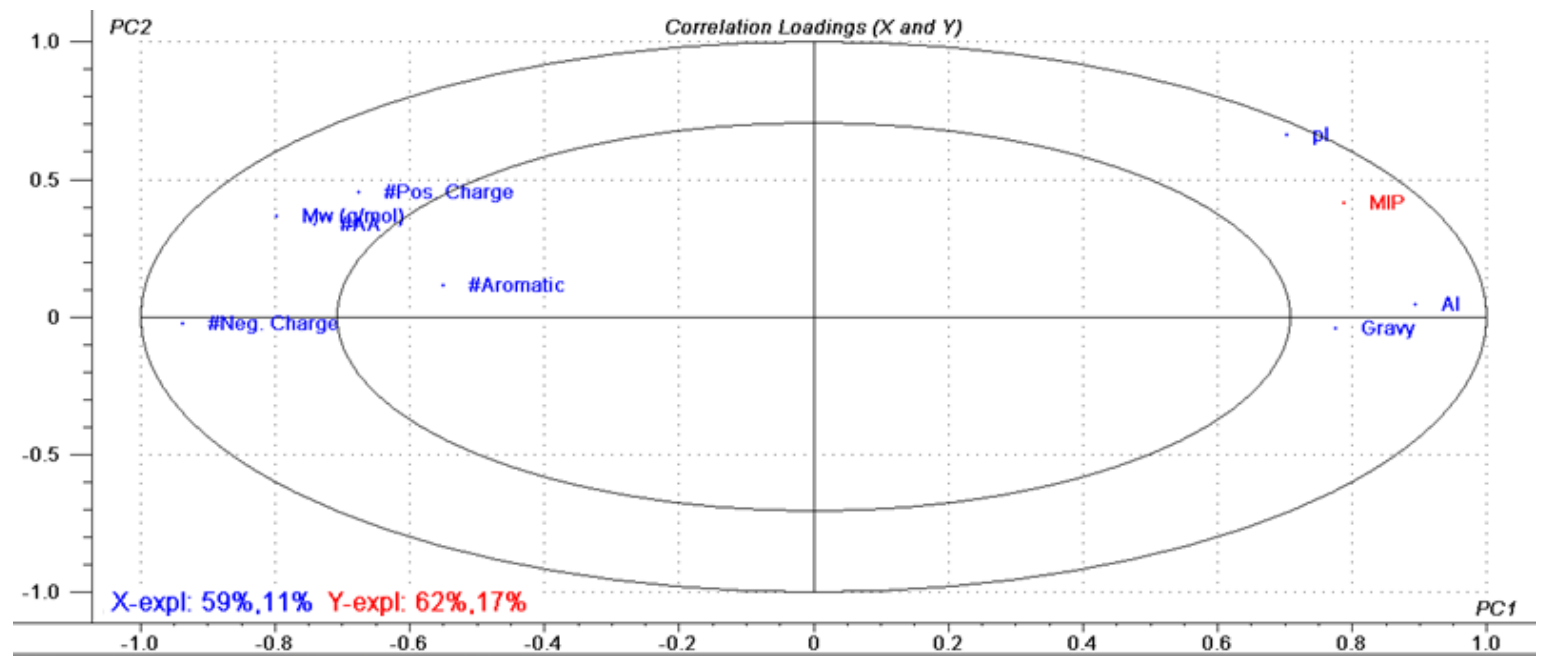

Figure 4 Correlation loadings plot of the MIP model on the first two components. 


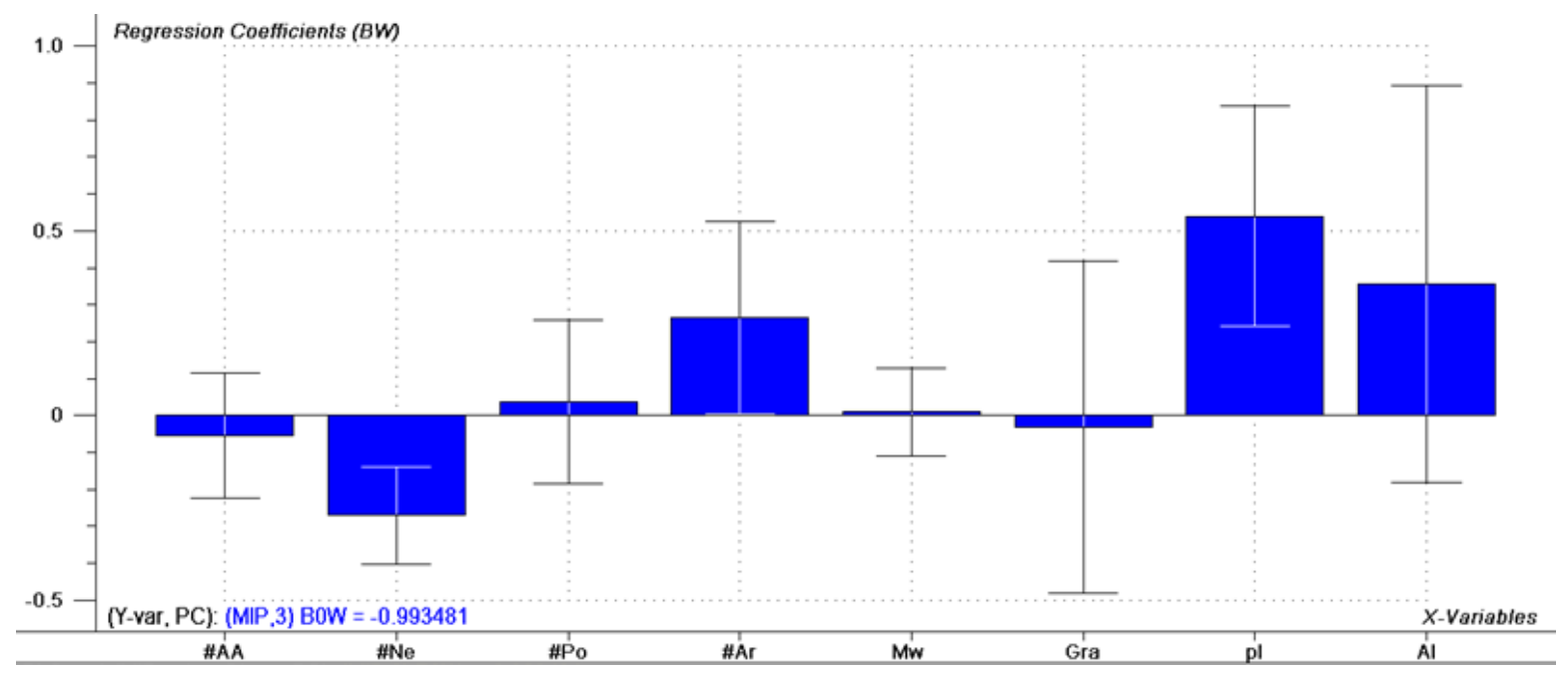

Figure 5 Regression coefficient of the MIP model for each descriptor: number of amino acids (\#AA), number of negative charges (\#Ne), number of positive charges (\#Po), number of aromatic residues (\#Ar), molecular weight (Mw), gravy index (Gra), isoelectric point (pl), aliphatic index (Al).

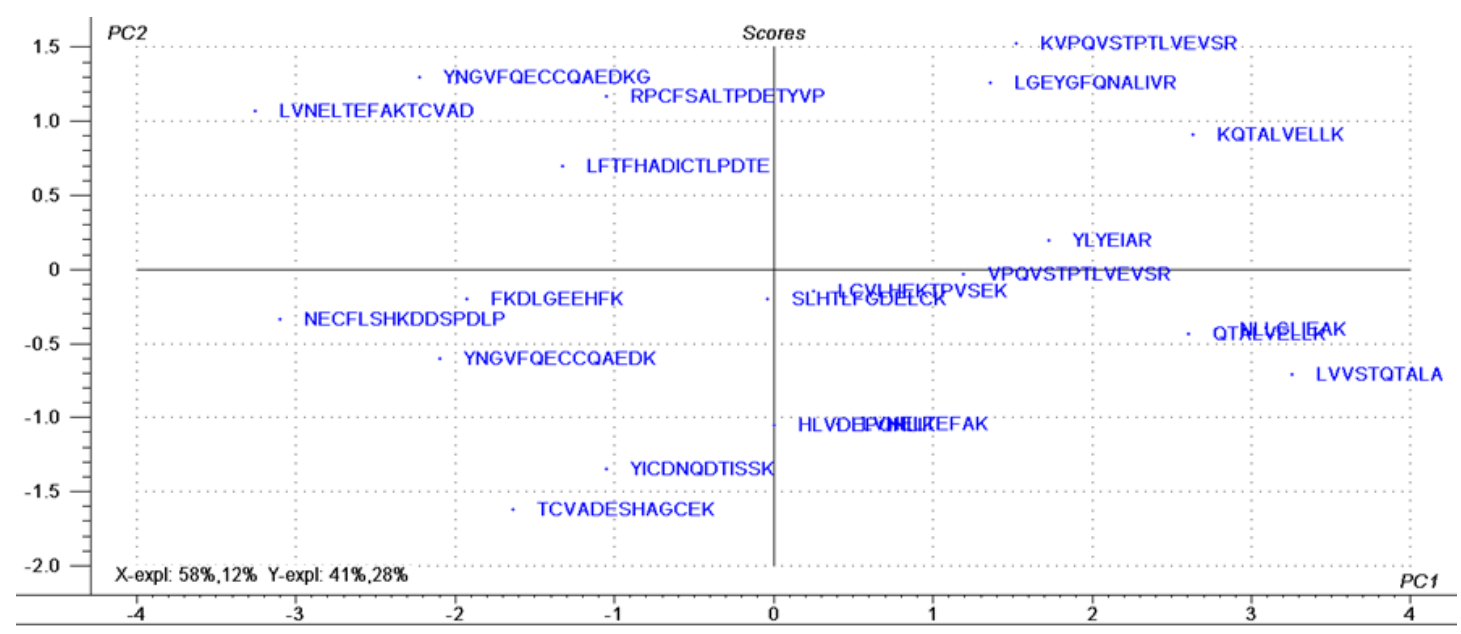

Figure 6 Score plot of the NIP model on the first two components. 


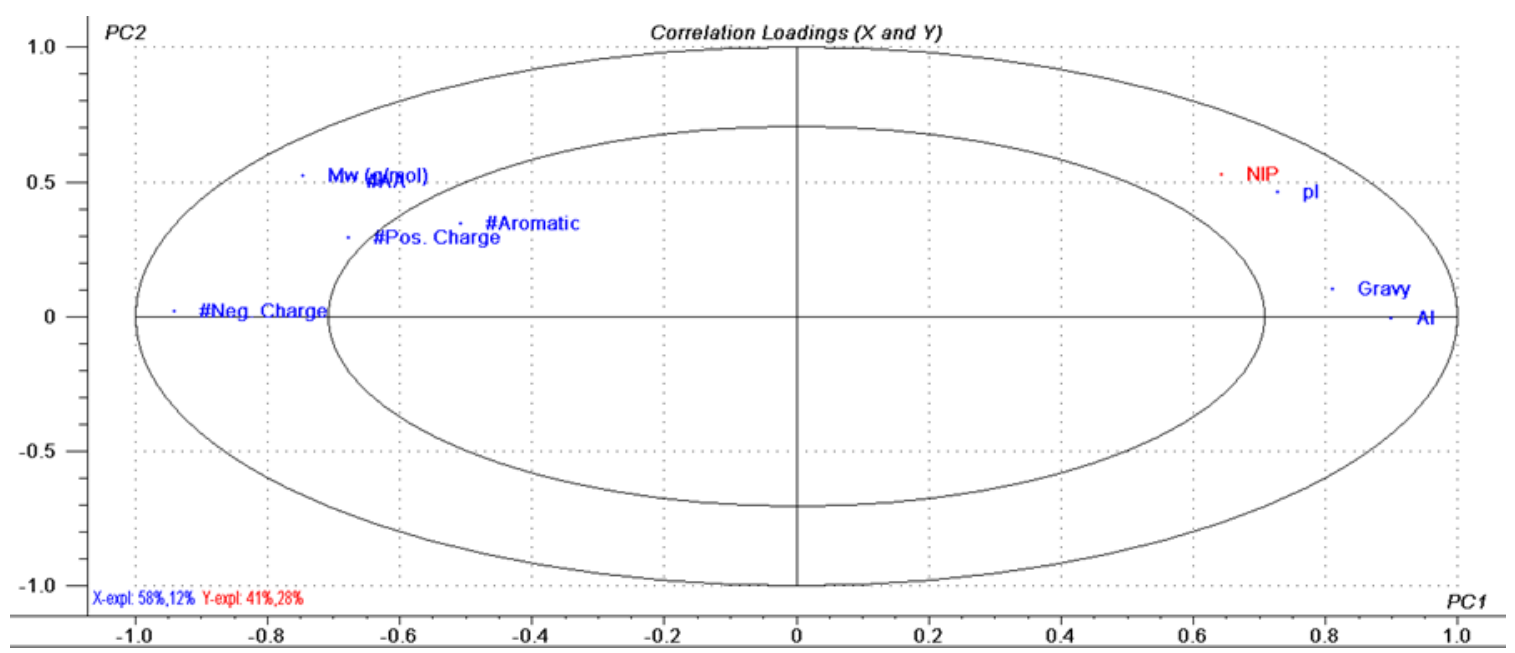

Figure 7 Correlation loadings plot of the NIP model on the first two components.

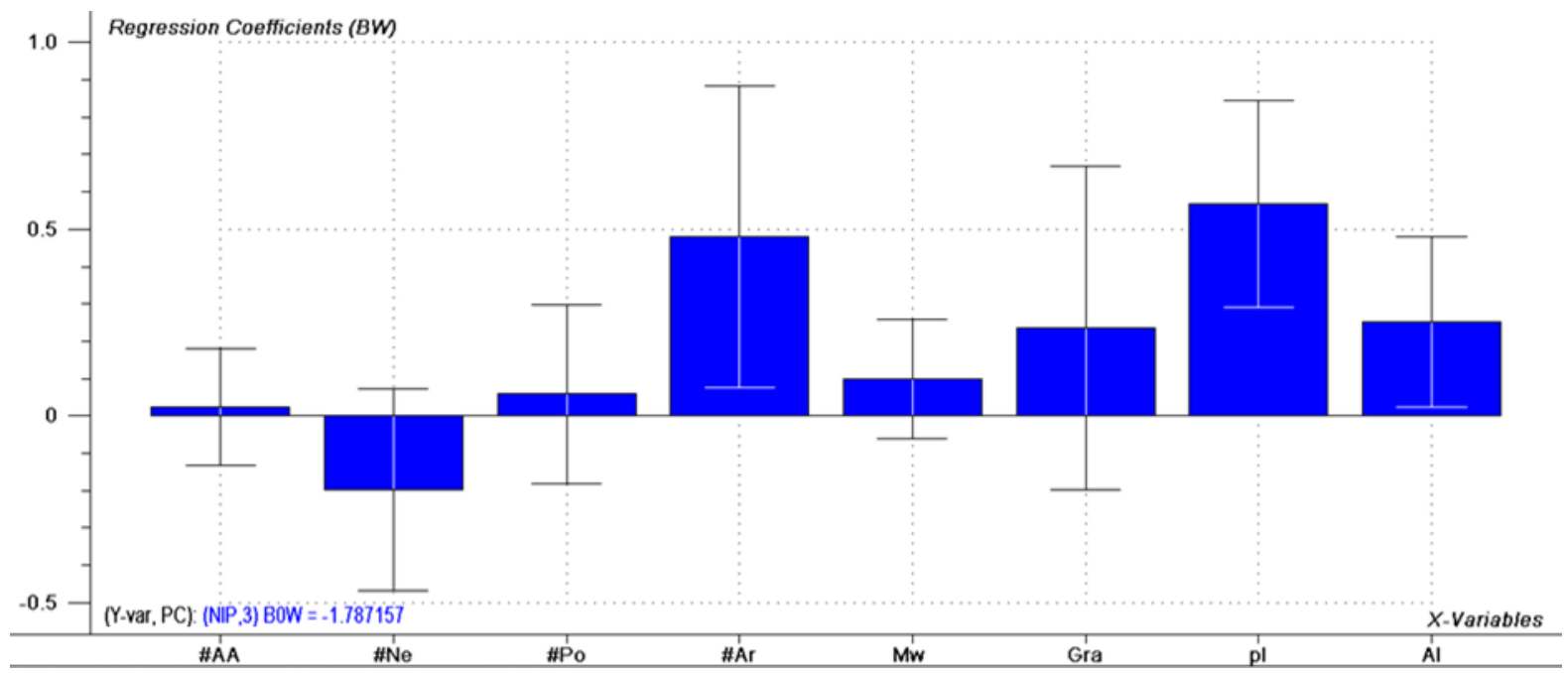

Figure 8 Regression coefficients of the NIP model for each descriptor: number of amino acids (\#AA), number of negative charges (\#Ne), number of positive charges (\#Po), number of aromatic residues (\#Ar), molecular weight (Mw), gravy index (Gra), isoelectric point ( $\mathrm{pl})$, aliphatic index (Al) 


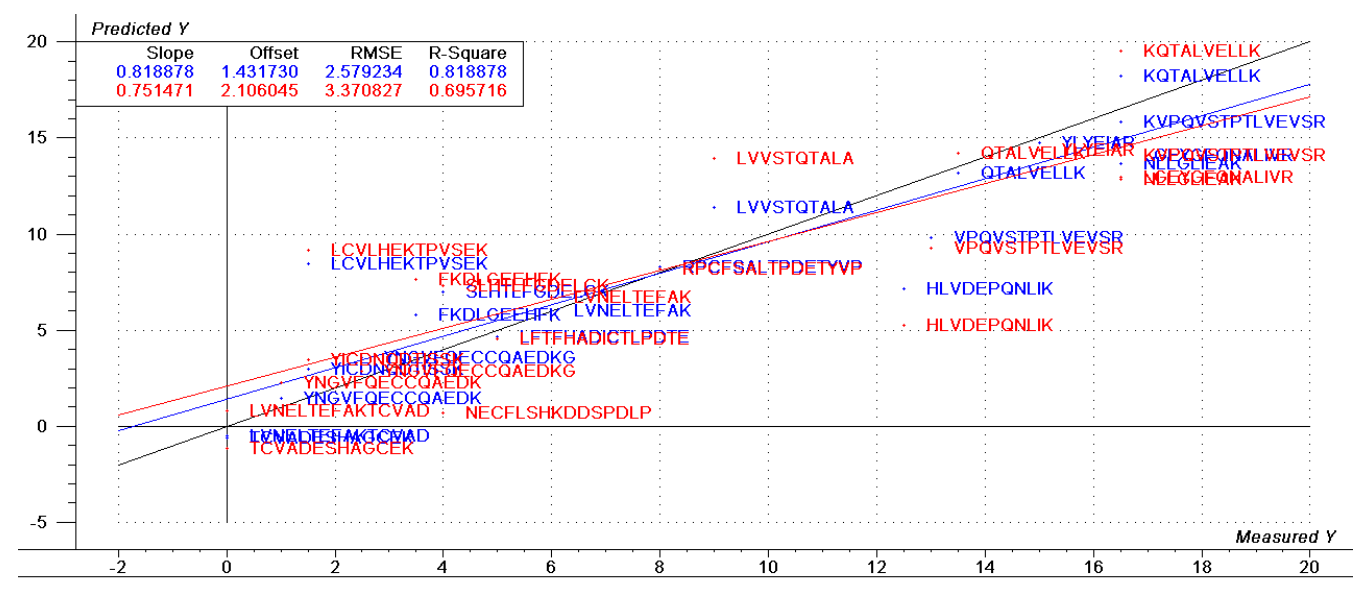

Figure 9 Plot of the Predicted vs Measured of the MIP regression model by calibration test set (blue) and validation set (red). The value of the line slope, offset, R- squared and root mean squared error (RMSE) are given for both the regression from calibration set (blue) and validation set (red).

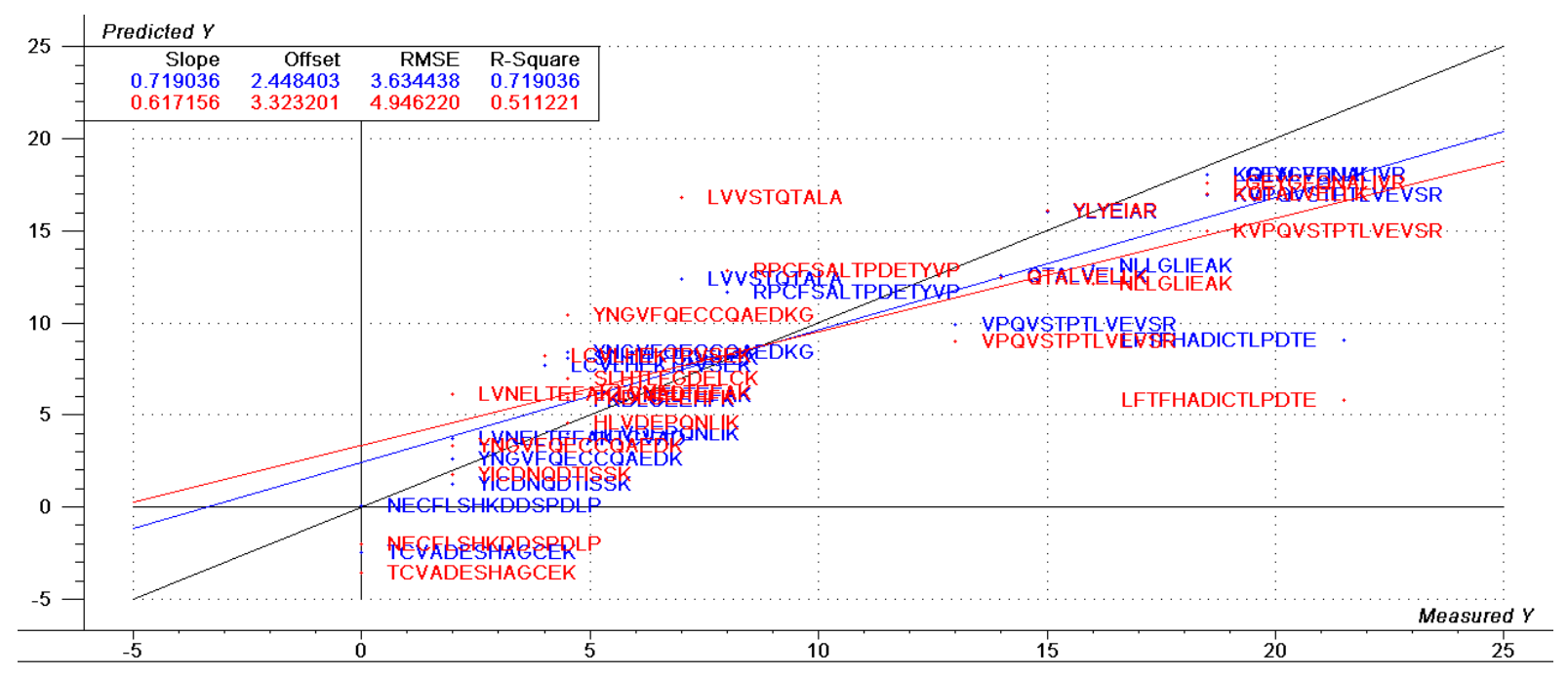

Figure 10 Plot of the Predicted vs Measured of the NIP regression model by calibration test set (blue) and validation set (red). The value of the line slope, offset, R- squared and root mean squared error (RMSE) are given for both the regression from calibration set (blue) and validation set (red). 


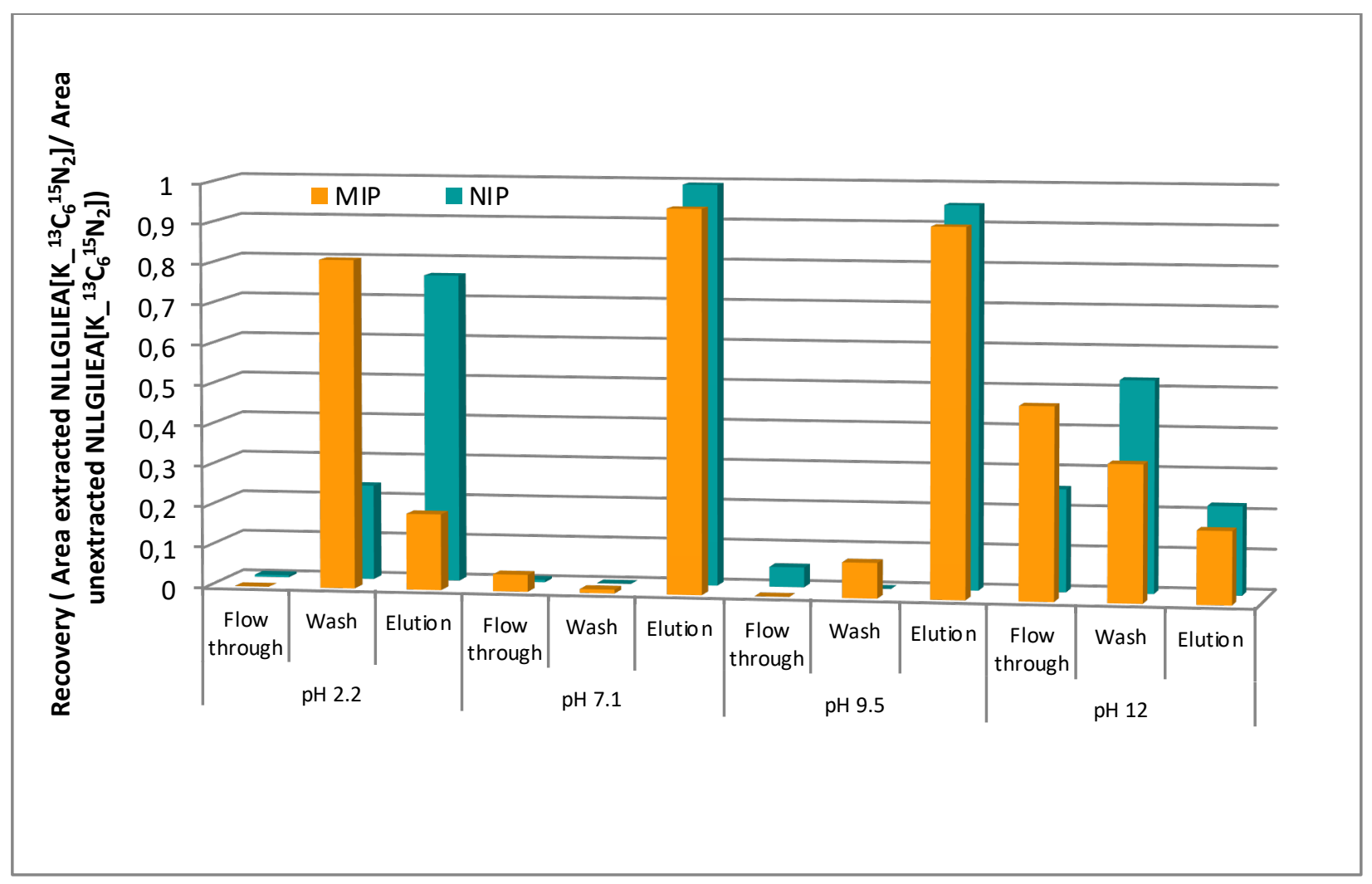

Figure 11 Influence of the loading pH on the NLLGLIEA $\left[\mathrm{K}_{-}{ }^{13} \mathrm{C}_{6}{ }^{15} \mathrm{~N}_{2}\right]$ recovery in all the collected SPE fractions (flow through, wash and elution).

\section{REFERENCES}

1. Sellergren, B., Molecularly imprinted polymers: Shaping enzyme inhibitors. Nature Chemistry 2010, 2 (1), 7-8.

2. Haupt, K., Biomaterials: Plastic antibodies. Nat. Mater. 2010, 9 (8), 612-614.

3. Beltran, A.; Borrull, F.; Marcé, R. M.; Cormack, P. A. G., Molecularly-imprinted polymers: useful sorbents for selective extractions. TrAC Trends in Analytical Chemistry 2010, 29 (11), 1363-1375.

4. Lanza, F.; Sellergren, B., The application of molecular imprinting technology to solid phase extraction. Chromatographia 2001, 53 (11), 599-611.

5. Tamayo, F. G.; Turiel, E.; Martín-Esteban, A., Molecularly imprinted polymers for solid-phase extraction and solid-phase microextraction: Recent developments and future trends. Journal of Chromatography A 2007, 1152 (1-2), 32-40.

6. Greibrokk, T., Molecular Imprinting in Separation Science. Journal of Separation Science 2016, 39 (5), 815-817.

7. Baggiani, C.; Anfossi, L.; Giovannoli, C., Solid phase extraction of food contaminants using molecular imprinted polymers. Analytica Chimica Acta 2007, 591 (1 SPEC. ISS.), 29-39.

8. Li, G.; Ma, G., Recent applications of solid-phase extraction techniques for analysis of trace residues and contaminants in food. Chinese Journal of Chromatography (Se Pu) 2011, 29 (7), 606-612. 9. Lok, C. M.; Son, R., Application of molecularly imprinted polymers in food sample analysis - A perspective. International Food Research Journal 2009, 16 (2), 127-140. 
10. Manesiotis, P.; Kashani, S.; McLoughlin, P., Molecularly imprinted polymers for the extraction of imiquimod from biological samples using a template analogue strategy. Analytical Methods 2013, 5 (12), 3122-3128.

11. Turiel, E.; Martín-Esteban, A., Molecularly imprinted polymers for sample preparation: A review. Analytica Chimica Acta 2010, 668 (2), 87-99.

12. Caro, E.; Marcé, R. M.; Borrull, F.; Cormack, P. A. G.; Sherrington, D. C., Application of molecularly imprinted polymers to solid-phase extraction of compounds from environmental and biological samples. TrAC - Trends in Analytical Chemistry 2006, 25 (2), 143-154.

13. Pardo, A.; Mespouille, L.; Dubois, P.; Duez, P.; Blankert, B., Targeted extraction of active compounds from natural products by molecularly imprinted polymers. Central European Journal of Chemistry 2012, 10 (3), 751-765.

14. Beltran, A.; Marcé, R. M.; Cormack, P. A. G.; Borrull, F., Synthesis by precipitation polymerisation of molecularly imprinted polymer microspheres for the selective extraction of carbamazepine and oxcarbazepine from human urine. Journal of Chromatography A 2009, 1216 (12), 2248-2253.

15. Beltran, A.; Borrull, F.; Cormack, P. A. G.; Marcé, R. M., Molecularly imprinted polymer with high-fidelity binding sites for the selective extraction of barbiturates from human urine. Journal of Chromatography A 2011, 1218 (29), 4612-4618.

16. Halhalli, M. R.; Aureliano, C. S. A.; Schillinger, E.; Sulitzky, C.; Titirici, M. M.; Sellergren, B., An improved grafting technique for producing imprinted thin film composite beads. Polymer Chemistry 2012, 3 (4), 1033-1042.

17. Cacho, C.; Turiel, E.; Martin-Esteban, A.; Pérez-Conde, C.; Cámara, C., Characterisation and quality assessment of binding sites on a propazine-imprinted polymer prepared by precipitation polymerisation. Journal of Chromatography B 2004, 802 (2), 347-353.

18. Valero-Navarro, Á.; Gómez-Romero, M.; Fernández-Sánchez, J. F.; Cormack, P. A. G.; SeguraCarretero, A.; Fernández-Gutiérrez, A., Synthesis of caffeic acid molecularly imprinted polymer microspheres and high-performance liquid chromatography evaluation of their sorption properties. Journal of Chromatography A 2011, 1218 (41), 7289-7296.

19. Baggiani, C.; Giovannoli, C.; Anfossi, L.; Passini, C.; Baravalle, P.; Giraudi, G., A Connection between the Binding Properties of Imprinted and Nonimprinted Polymers: A Change of Perspective in Molecular Imprinting. Journal of the American Chemical Society 2012, 134 (3), 1513-1518.

20. Baggiani, C.; Giovannoli, C.; Anfossi, L., Man-made synthetic receptors for capture and analysis of ochratoxin A. Toxins 2015, 7 (10), 4083-4098.

21. Dechtrirat, D.; Jetzschmann, K. J.; Stöcklein, W. F. M.; Scheller, F. W.; Gajovic-Eichelmann, N., Protein rebinding to a surface-confined imprint. Advanced Functional Materials 2012, 22 (24), 52315237.

22. Pan, G.; Guo, Q.; Ma, Y.; Yang, H.; Li, B., Thermo-responsive hydrogel layers imprinted with RGDS peptide: A system for harvesting cell sheets. Angewandte Chemie - International Edition 2013, 52 (27), 6907-6911.

23. Li, D. Y.; Qin, Y. P.; Li, H. Y.; He, X. W.; Li, W. Y.; Zhang, Y. K., A "turn-on" fluorescent receptor for detecting tyrosine phosphopeptide using the surface imprinting procedure and the epitope approach. Biosensors and Bioelectronics 2015, 66, 224-230.

24. Li, Q.; Shen, F.; Zhang, X.; Hu, Y.; Zhang, Q.; Xu, L.; Ren, X., One-pot synthesis of phenylphosphonic acid imprinted polymers for tyrosine phosphopeptides recognition in aqueous phase. Analytica Chimica Acta 2013, 795, 82-87.

25. Xu, L.; Hu, Y.; Shen, F.; Li, Q.; Ren, X., Specific recognition of tyrosine-phosphorylated peptides by epitope imprinting of phenylphosphonic acid. Journal of Chromatography A 2013, 1293 (0), 85-91. 
26. Stevenson, D.; El-Sharif, H. F.; Reddy, S. M., Selective extraction of proteins and other macromolecules from biological samples using molecular imprinted polymers. Bioanalysis 2016, 8 (21), 2255-2263.

27. Zhu, W.; Jiang, G.; Xu, L.; Li, B.; Cai, Q.; Jiang, H.; Zhou, X., Facile and controllable one-step fabrication of molecularly imprinted polymer membrane by magnetic field directed self-assembly for electrochemical sensing of glutathione. Analytica Chimica Acta 2015, 886, 37-47.

28. Liu, L.; Zhong, T.; Xu, Q.; Chen, Y., Efficient Molecular Imprinting Strategy for Quantitative Targeted Proteomics of Human Transferrin Receptor in Depleted Human Serum. Analytical Chemistry 2015, 87 (21), 10910-10919.

29. Riveros G, D.; Cordova, K.; Michiels, C.; Verachtert, H.; Derdelinckx, G., Polydopamine imprinted magnetic nanoparticles as a method to purify and detect class II hydrophobins from heterogeneous mixtures. Talanta 2016, 160, 761-767.

30. Urraca, J. L.; Aureliano, C. S. A.; Schillinger, E.; Esselmann, H.; Wiltfang, J.; Sellergren, B., Polymeric complements to the Alzheimer's disease biomarker $\beta$-amyloid isoforms A $\beta 1-40$ and a $\beta 1-42$ for blood serum analysis under denaturing conditions. Journal of the American Chemical Society 2011, 133 (24), 9220-9223.

31. Xu, L.; Hu, Y.; Shen, F.; Li, Q.; Ren, X., Specific recognition of tyrosine-phosphorylated peptides by epitope imprinting of phenylphosphonic acid. Journal of Chromatography $A$ 2013, 1293, 85-91.

32. Tan, L.; Yu, Z.; Zhou, X.; Xing, D.; Luo, X.; Peng, R.; Tang, Y., Antibody-free ultra-high performance liquid chromatography/tandem mass spectrometry measurement of angiotensin I and II using magnetic epitope-imprinted polymers. Journal of Chromatography A 2015, 1411, 69-76.

33. Tai, D. F.; Lin, Y. F.; Lu, K. H.; Chen, G. Y.; Shu, H. C., A direct immersion system for peptide enrichment. Journal of the Chinese Chemical Society 2012, 59 (3), 338-344.

34. Helling, S.; Shinde, S.; Brosseron, F.; Schnabel, A.; Müller, T.; Meyer, H. E.; Marcus, K.; Sellergren, B., Ultratrace enrichment of tyrosine phosphorylated peptides on an imprinted polymer. Analytical Chemistry 2011, 83 (5), 1862-1865.

35. Chen, J.; Shinde, S.; Koch, M. H.; Eisenacher, M.; Galozzi, S.; Lerari, T.; Barkovits, K.; Subedi, P.; Krüger, R.; Kuhlmann, K.; Sellergren, B.; Helling, S.; Marcus, K., Low-bias phosphopeptide enrichment from scarce samples using plastic antibodies. Scientific Reports 2015, 5.

36. Qader, A. A.; Urraca, J.; Torsetnes, S. B.; Tønnesen, F.; Reubsaet, L.; Sellergren, B., Peptide imprinted receptors for the determination of the small cell lung cancer associated biomarker progastrin releasing peptide. Journal of Chromatography A 2014, 1370, 56-62.

37. Rossetti, C.; Levernæs, M. C. S.; Reubsaet, L.; Halvorsen, T. G., Evaluation of affinity-based serum clean-up in mass spectrometric analysis: Plastic vs monoclonal antibodies. Journal of Chromatography $A$ 2016, 1471, 19-26.

38. Žuvela, P.; Liu, J. J.; Macur, K.; Baczek, T., Molecular Descriptor Subset Selection in Theoretical Peptide Quantitative Structure-Retention Relationship Model Development Using Nature-Inspired Optimization Algorithms. Analytical Chemistry 2015, 87 (19), 9876-9883.

39. Malmquist, G.; Nilsson, U. H.; Norrman, M.; Skarp, U.; Strömgren, M.; Carredano, E., Electrostatic calculations and quantitative protein retention models for ion exchange chromatography. Journal of Chromatography A 2006, 1115 (1-2), 164-186.

40. Houbart, V.; Cobraiville, G.; Nys, G.; Merville, M. P.; Fillet, M., Impact of injection solvent composition on protein identification in column-switching chip-liquid chromatography/mass spectrometry. Journal of Chromatography A 2016, 1445, 27-35.

41. Houbart, V.; Rozet, E.; Matagne, A.; Crommen, J.; Servais, A. C.; Fillet, M., Influence of sample and mobile phase composition on peptide retention behaviour and sensitivity in reversed-phase liquid chromatography/mass spectrometry. Journal of Chromatography A 2013, 1314, 199-207. 
42. Rossetti, C.; Abdel Qader, A.; Halvorsen, T. G.; Sellergren, B.; Reubsaet, L., Antibody-free biomarker determination: Exploring molecularly imprinted polymers for pro-gastrin releasing peptide. Analytical Chemistry 2014, 86 (24), 12291-12298.

43. Consortium, T. U., UniProt: a hub for protein information. Nucleic Acids Research 2015, 43 (D1), D204-D212.

44. Martens, H.; Martens, M., Modified Jack-knife estimation of parameter uncertainty in bilinear modelling by partial least squares regression (PLSR). Food Quality and Preference 2000, 11 (1-2), 5-16. 